\title{
A tribute to the late Professor Jean-Pierre Berger (8 July 1956-18 January 2012)
}

\author{
Damien Becker · Daniel Marty · Claudius Pirkenseer • Lionel Cavin • \\ Kirsten Grimm • Bettina Reichenbacher
}

Published online: 16 November 2013

(c) Swiss Geological Society 2013

Keywords Palaeontology - Biostratigraphy · Chronostratigraphy $\cdot$ Vertebrata $\cdot$ Invertebrata . Mammalia $\cdot$ Charophyta

Professor Jean-Pierre Berger joined the Fribourg University (Switzerland) in 1989 as a lecturer (chargé de cours), quickly rising to the rank of head assistant with a postdoctoral lecture qualification in 1992, and becoming Associate Professor for palaeontology in 1997. Fribourg, Lausanne, Tübingen and Munich were important places in his professional career.

From the beginning, his scientific interests encompassed a broad variety of topics. He started his career as a biostratigrapher, palaeobotanist and quickly became a renowned specialist for Cenozoic charophytes. Until 2003, he was coordinator of the Group of European

D. Becker $(\bowtie)$

Musée jurassien des sciences naturelles, Route de Fontenais 21,

2900 Porrentruy, Switzerland

e-mail: damien.becker@jura.ch

\section{Marty}

Paléontologie A16, Section d'archéologie et paléontologie,

Office de la culture, Hôtel des Halles, P.O. Box 64, 2900

Porrentruy 2, Switzerland

e-mail: daniel.marty@palaeojura.ch

\section{Pirkenseer}

Unit Earth Sciences, Université de Fribourg,

Chemin du Musée 6, 1700 Fribourg, Switzerland

e-mail: claudiusmarius.pirkenseer@unifr.ch

L. Cavin

Department of Geology and Palaeontology, Muséum d'Histoire

Naturelle, CP 6434, 1211 Geneve 6, Switzerland

e-mail: lionel.cavin@ville-ge.ch
Charophytologists. Apart from his exceptional contributions to taxonomy (Berger 1983a, 1992a, b), Jean-Pierre established and improved the application of charophytes as a tool in biostratigraphic zonation (Berger 1983b, 1986, 1992c, 1999; Riveline et al. 1996), and recognized the outstanding importance of stratigraphy for all Earth Sciences-related disciplines. This approach led him to his second research focus, building supra-regional fine-stratigraphic correlation charts that incorporate the most important fossil groups (Berger 1992c; Berger et al. 2005a), and constructing high-resolution, palinspastic palaeogeographic maps (Berger 1996; Berger et al. 2005b). Later on, Jean-Pierre got also interested in mammals, and together with Damien Becker launched a National Research Foundation project in 2007 on the terrestrial palaeoecosystems of Early Oligocene to the Early Miocene large mammals from Western Europe.

\footnotetext{
K. Grimm

Naturhistorisches Museum Mainz/Landessammlung für Naturkunde Rheinland-Pfalz, Reichklarastr.10,

55116 Mainz, Germany

e-mail: kgrimm@uni-mainz.de

B. Reichenbacher

Department of Earth- and Environmental Sciences, Palaeontology and Geobiology, Ludwig-MaximiliansUniversity, Richard-Wagner-Strasse 10, 80333 Munich, Germany e-mail: b.reichenbacher@1rz.uni-muenchen.de
} 
Jean-Pierre always tried to explore the overall picture and continuously initiated new collaborations with scientists from other Earth Science disciplines. He was cofounder, creative director and spirit of the "Molassegroup" (an informal assembly of earth scientists interested in the North Alpine Foreland Basin and the Paratethys), and repeatedly organised the annual or biannual meetings of this group. Moreover, Jean-Pierre was a highly renowned and sought-after specialist and made significant contributions to several international and interdisciplinary research projects, including the European Science Foundation projects EUCOR-URGENT (2000-2004, dedicated to the geology of the Upper Rhine Graben), EEDEN (2000-2004, focusing on Neogene palaeoecology and palaeogeography), and the Regional Committee on Mediterranean Neogene Stratigraphy (RCMNS).

Additionally, he was active in numerous Swiss scientific committees: he was the chairman of the Swiss Working Group for Geotopes (Swiss Academy of Sciences), vicepresident of the "Kommission für die Schweizerischen Paläontologischen Abhandlungen" ("Commission des Mémoires Suisses de Paléontologie"), and he was a member in the Swiss Commission for Stratigraphy and the Swiss Geological Commission. Jean-Pierre also was very active in the Swiss Palaeontological Society, bringing together professionals and amateurs, where he was a faithful member in the committee for more than 20 years.

Furthermore, Jean-Pierre was significantly involved in the foundation of the "Paléontologie A16" in the year 2000, and he became one of two scientific commissaries of this unique palaeontological survey project. This project, financed by the Swiss Federal Roads Authority (FEDRO, $95 \%$ ) and the Canton Jura (5\%), is mandated to excavate, document, and safeguard the paleontological heritage prior to the construction of Highway A16, and to make it accessible for scientific research (e.g., Hug et al. 2004; Ayer et al. 2006). Due to the multitude of important discoveries made on the future course of Highway A16, including the "Oligocene fossil forest" near Delémont (Clément and Berger 1999; Becker 2003; Becker and Lapaire 2004; Becker et al. 2004; Picot et al. 2008) and internationally renowned dinosaur tracksites (e.g., Marty et al. 2003, 2007, 2010; Marty 2008), the Canton Jura decided in 2008 to establish a cantonal project initially named "Paléojura" (today replaced by the "Fondation Jules Thurmann") in order to valorise the palaeontological and natural heritage. From the beginning, Jean-Pierre strongly supported this project and significantly contributed to the elaboration of a master plan, and the "scientific axis" of the project by establishing the link to the Swiss Universities (notably Fribourg) and the Swiss Academy of Sciences.

Regardless of all these many activities, Jean-Pierre Berger published about 60 scientific articles plus numerous conference contributions. The list of his co-authors, among them many of his students and $\mathrm{PhD}$ students, is long (e.g., Becker et al. 2001, 2002, 2004, 2011; Picot et al. 1999, 2005, 2008; Kälin et al. 2001; Emery et al. 2007; Mennecart et al. 2009, 2010, 2012; Pirkenseer et al. 2010, 2011; Scherler et al. 2010, 2011), and demonstrates his high collegiality and, above all, his high social sense of responsibility towards his students and $\mathrm{PhD}$ students, and principally towards all young academics, which he always enthusiastically supported. Furthermore, he gave numerous popular talks, wrote lively popular-scientific contributions (e.g., Berger 1987; Berger and Dupraz 1995; Emmenegger et al. 2003), and was always available for any requests of the media.

Jean-Pierre also was a gifted teacher in palaeontology and geology, not only in the lecture halls but also in the field, during excursions and field courses (Fig. 1). He always loved to explore abandoned and forgotten quarries or new sites located in virtually impassable terrain, and due to his peculiar personality and charm he could convince companies to grant admission to core drillings that were not accessible previously. Jean-Pierre was aware of the fact that teaching is an important and rewarding task, and accordingly his commitment to teaching was considerable. He lectured the entire spectrum of palaeontology, and his excellent teaching credentials, outstanding personality and charisma have always attracted plenty of students. Certainly, he has contributed to the continuity of the palaeontological discipline at the University of Fribourg, within the Swiss academic system, but also to the awareness of local and national politicians responsible for research and education (Fig. 1).

However, it was not sufficient for Jean-Pierre to be an excellent natural scientist, palaeontologist, and academic teacher. He was also active in local affairs and during many years he acted as a municipal councillor for his home community, where he actively worked innumerable hours with his peculiar enthusiasm.

In spite of all these professional activities and commitments, Jean-Pierre always remained unfailingly polite and motivated, full of new ideas and, above all, full of vitality and "joie de vivre". During his life, he loved the art of singing and shared his passion with numerous friends, the youngsters from the choir of the Collège St Michel, the students from the University choirs at Fribourg and Munich, and especially the members of the church choir Corpataux.

To conclude, Jean-Pierre's accomplishments were many, as he was a palaeontologist who studied and published original findings in fossil invertebrates and vertebrates, stratigraphy, and geology. He manifested this broad interest in being active in numerous societies and committees, but also by wearing $\mathrm{T}$-shirts with 


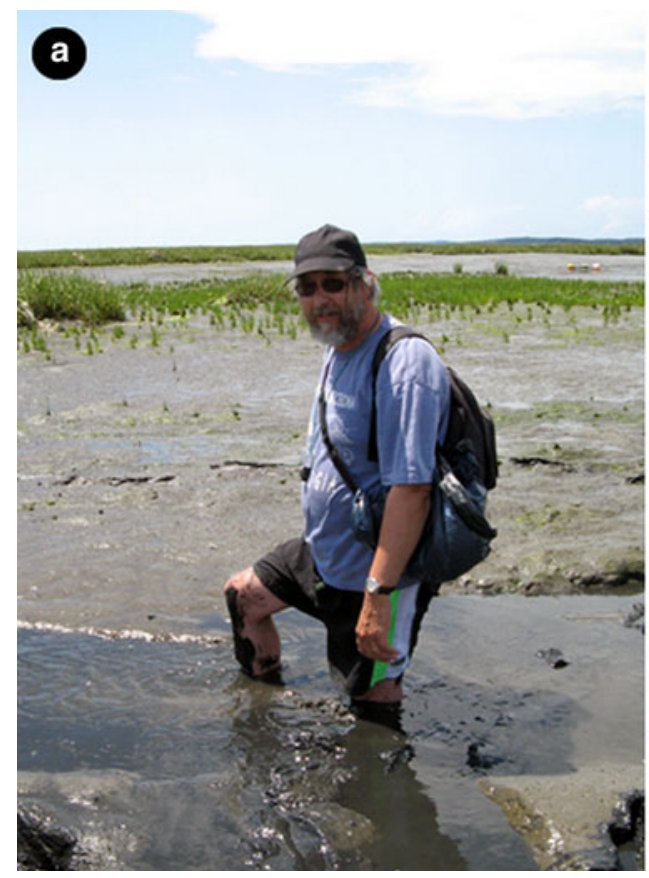

Fig. 1 a Jean-Pierre Berger exploring a recent tidal flat environment during a field course of the University of Fribourg in Arcachon (France) in 2009. b Meeting with Moritz Leuenberger, member of the Swiss Federal Council, at the 3rd Festival Science et Cité

palaeontological themes. There is certainly much more to be said about Jean-Pierre, who is irreplaceable and will live on in our memory and in our hearts. We not only lost an outstanding scientist whose contributions have a profound international impact, but also a highly valuable friend, who treated his colleagues, collaborators, and students as friends and peers, and who strongly and positively influenced the careers and lives of many of them. Professor Jean-Pierre Berger died much too early on January 18th 2012, at the age of 56 .

\section{The special issue}

The present full-colour Special Issue of the Swiss Journal of Geosciences is a tribute to the late Prof. Jean-Pierre Berger. It assembles 22 scientific papers covering a wide spectrum of palaeontological, stratigraphical, and geological research, that reflect the broad scientific research interests of Jean-Pierre. The contributions are from active researchers and research-groups, mostly colleagues of Jean-Pierre. They cover a wide range of topics with the main focus on vertebrate palaeontology (Cenozoic mammals, birds and fishes; Mesozoic sauropsids and fishes) and invertebrate palaeontology (Cenozoic charophytes, foraminifers, ostracods and plants; Mesozoic ophiuroids, brachiopods, ostracods and foraminifers). Yet other papers

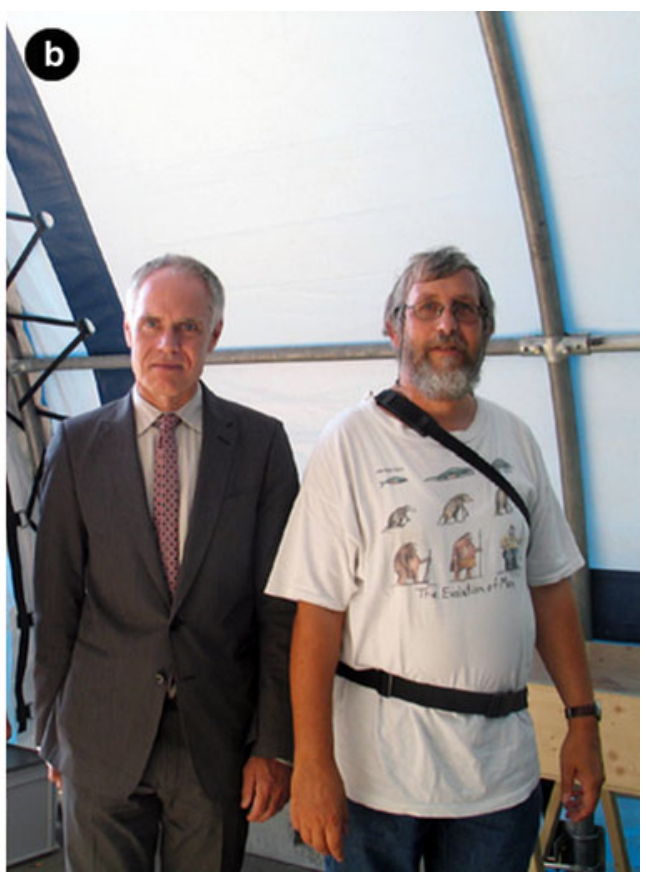

BaseCamp09 that was organised in the UN-supported International Year of the Planet (IYPE) as a touring exhibition with stops in six cities in Switzerland, and where Jean-Pierre Berger was responsible for the theme "La Terre et la vie"

focus on regional geology, magnetostratigraphy, and lithostratigraphy. The high diversity of these up-to-date papers underlines that palaeontological research in Switzerland clearly is alive, that new important discoveries are continuously made, and it also highlights the importance of interdisciplinary scientific research in Earth Sciences. Therefore, the present Special Issue is a useful and interesting lecture for palaeontologists, amateur fossil collectors, and geologists alike.

The contributions appear in alphabetical order, preceded by a publication with Jean-Pierre Berger as first author. This paper in French has the title "Un curieux microfossile de la Molasse oligocène de Suisse occidentale et de HauteSavoie (France)", and it deals with Oligocene enigmatic plant fossils, on which Jean-Pierre started working over 30 years ago. This paper is a collaboration with Marc Weidmann, who finalized the manuscript together with Margaret E. Collinson. Jean-Pierre is also co-author in the publication of Pirkenseer et al., and some of the charophytes they describe figure as cover illustration of volume 106 (year 2013) of the Swiss Journal of Geosciences.

Two new species are named "bergeri" in honour of Jean-Pierre Berger: Eozonella bergeri gen. et sp. nov. (ophiuroid, Late Oxfordian, Boncourt, Thuy et al.), and ?Oligostrix bergeri sp. nov. (owl, Oligocene, Mümliswil, de Pietri et al.). In total, three new taxa and five new species are described and, besides the above mentioned, 
include: Pacorichthys sangiorgii gen. et sp. nov. (basal actinopterygian fish, Late Ladinian, Monte San Giorgio, Lombardo), Macrocnemus obristi sp. nov. (protorosaur, Middle Triassic, Ducanfurgga, Fraser and Furrer), and Juracantha hottingeri gen. et sp. nov. (ophiuorid, Late Oxfordian, Boncourt, Thuy et al.).

With 15 out of 22 contributions, the major focus of the present Special Issue is on Cenozoic material, notably micro- and macromammal remains. Four new micromammal faunas are described, representing important additional data for biostratigraphical zonations and palaeobiogeographical reconstructions: Dürrenberg (Switzerland, Oligocene, Kälin), Chrummorge (Lägern, Switzerland, Late Oligocene, Bolliger), Mazan (Vaucluse, France, Early Oligocene, Maridet el al.), and the rodent Kardyomys from the Höll and Laimering 3 localities (Bavaria, Germany, Middle Miocene, Prieto and Scholz).

Rössner and Heissig describe new records of Dorcatherium guntianum and discuss the diphyletic origin of European tragulids; Antoine and Becker present a review of Agenian (Early Miocene) rhinocerotids from Western Europe; and Orliac et al. suggest amphibiosis in Brachyodus onoideus (Artiodactyla, Hippopotamoidae, Early Miocen) based on the dissection of the left auditory region allowing the extraction of the left petrosal bone. Scherler et al. discuss the evolutionary history of hoofed mammals during the Oligocene-Miocene transition in Western Europe and, based on faunal balances, poly-cohorts and particularly cluster analyses, introduce the Microbunodon faunal Event that has a high significance in the reorganisation of European, hoofed-mammal communities. De Pietri et al. review the fossil avifauna of Switzerland from Eocene fissure fillings and Oligocene Molasse deposits. They report new material discovered in the collections of the Natural History Museum Basel including the first record of a fossil owl from Switzerland.

Pirkenseer et al. analyse the Late Rupelian marine regression in the southern Upper Rhine Graben based on new records of microfossils (fish otoliths, Bolboforma, Charophyta) from two boreholes, and they propose a younger position of the Rupelian/Chattian boundary than previously assumed. Based on integrated magneto-lithobiostratigraphic studies on four sections and three boreholes from the Swiss and South German Molasse Basin, Reichenbacher et al. introduce a new chronostratigraphic framework for the Lower Miocene of the North Alpine Foreland Basin that is important for correlations within the Paratethys domain, and for the Global Time Scale. Mastrangelo et al. report on tectonically important new Molasse rouge (Paleogene) outcrops on the Salève, demonstrating a more complex connection of the eastern flank of the Salève Mountains with the adjacent plateau des Bornes than was previously assumed.
Furthermore, the present Special Issue also comprises three contributions on fossil fishes. Pictet et al. describe a new assemblage of ray-finned fishes (Teleostei) from the Lower Oligocene "Schistes à Meletta" (Glières Plateau, Bornes Massif, Eastern France). Cavin et al. present new coelacanth material from the Middle Triassic Prosanto Formation of the Ducan and Landwasser area (Canton Graubünden, Eastern Switzerland), and comment on the taxonomic diversity of actinistans, as the new Ticinepomis material shows anatomical features not preserved on the holotype. Lombardo describes a new taxon of a Late Ladinian basal actinopterygian from the Meride Limestone (Monte San Giorgio, Canton Ticino, Switzerland) resembling the condition of the Redfieldiiformes, a freshwater fish group, whose presence in Europe is still controversial.

Four additional contributions treat various Mesozoic fossil material. Sulser et al. describe little-known brachiopods from the Early Cretaceous of the Helvetic realm of the Alpstein and Voralberg (NE Switzerland and W Austria). Two contributions present Late Jurassic microfossils from excavations along Highway A16 in the Jura Canton. Schudack et al. focus on Kimmeridgian ostracods, which allow to interpret palaeosalinity, to confirm the stratigraphical subdivision of the Kimmeridgian as inferred from the ammonite biozonation, and to suggest that the Northern Swiss Jura Mountains belong to a largely boreally-influenced "Western and Central European subprovince". Thuy et al. describe exceptionally wellpreserved and partially-articulated, Late Oxfordian ophiuroids from a shallow subtidal environment. This ophiuroid assemblage has a family level composition that is highly unusual with respect to modern equivalents, and it is reminiscent of modern bathyal assemblages. Fraser and Furrer describe a new species of the protorosaur Macrocnemus from the Ladinian Prosanto Formation of the Eastern Swiss Alps, based on two incomplete specimens, one of which with soft part preservation in the region of the pelvic girdle and a fully-articulated hind part allowing a complete count of the caudal vertebrae.

Finally, Constandache et al. present a new methodological approach for internal pore measurements on macroperforate planktonic Foraminifera as an alternative morphometric approach. They demonstrate that, by measuring individual pores from inside the shell, it is possible to obtain abundant precise data either on individual or population level.

This Special Issue would not have been possible without the great help of the associate editors and reviewers (in alphabetical order): Michael J. Benton, Maria Aleksandra Bitner, Estelle Bourdon, Toni Bürgin, Loïc Costeur, Hugo Dutel, Matthijs Freudenthal, Danièle Gaspard, Jean Gaudant, Růžena Gregorová, Matthias Claudius Grimm, Patrick Grunert, David A.T. Harper, Kurt Heissig, Elmar 
Heizmann, Martin Hottenrott, John W.M. Jagt, Daniel Kaelin, Oliver Kempf, Pascal Kindler, Adriana López-Arbarello, Gerald Mayr, Grégoire Métais, Christian A. Meyer, Jon Mosar, Maria Rose Petrizzo, Jérôme Prieto, Bettina Reichenbacher, Silvio Renesto, Laureline Scherler, Torsten Scheyer, Ralf Schiebel, Sevket Sen, Ekaterina Tesakova, Jessica Theodor, Lars van den Hoek, Monique Vianey-Liaud, Andrew Wendruff, and Ian Wilkinson. We heartily acknowledge their great investment of time and support, indispensable to guarantee the high quality of the present original research articles.

Acknowledgments We would like to thank the Swiss Palaeontological Society for financial support for page charges of several contributions. Also, we would like to thank the Swiss Geological Society and the Swiss Mineralogical Society for agreeing to dedicate this entire second issue 2013 of the Swiss Journal of Geosciences to Jean-Pierre Berger.

\section{References}

Ayer, J., Becker, D., Billon-Bruyat, J.-P., Hug, W. A., \& Marty, D. (2006). Ausgrabung und Analyse von Fossilien der Autobahn A16 (Les fossiles de la Transjurane (A16): de la fouille à l'interprétation). Schweizer Strahler (Le Cristallier Suisse), 4(2006), 10-18.

Becker, D. (2003). Paléoécologie et paléoclimats de la Molasse du Jura (Oligo-Miocène): apport des Rhinocerotoidea (Mammalia) et des minéraux argileux. GeoFocus, 9, 327.

Becker, D., Antoine, P.-O., Engesser, B., Hiard, F., Hostettler, B., Menkveld-Gfeller, U., et al. (2011). Late Aquitanian mammals from Engehalde (Molasse Basin, Canton Bern, Switzerland). Annales de Paléontologie, 96, 95-116.

Becker, D., \& Lapaire, F. (2004). La Molasse du Jura (Cénozoïque): Premiers résultats des fouilles et recherches sur le tracé de la Transjurane (A16). Actes de la Société jurassienne d'Emulation, 106, Porrentruy, 45-61.

Becker, D., Lapaire, F., Picot, L., Engesser, B., \& Berger, J.-P. (2004). Biostratigraphie et palécologie du gisement à vertébrés de la Beuchille (Oligocène, Jura, Suisse). Revue de Paléobiologie, vol. spéc. 9, 179-191.

Becker, D., Picot, L., \& Berger, J.-P. (2002). Stable Isotopes $\left({ }^{13} \mathrm{C}\right.$, ${ }^{18} \mathrm{O}$ ) on charophytes gyrogonites: example from the Brochene Fluh section (Late Oligocene-Early Miocene/Switzerland). Geobios, 35, 89-97.

Becker, D., Rössner, G. E., Picot, L., \& Berger, J.-P. (2001). Early Miocene Ruminants of Wallenried (USM, Aquitanian/Switzerland): sedimentology, biostratigraphy and paleoecology. Eclogae Geologicae Helvetiae, 94(3), 547-564.

Berger, J.-P. (1983a). Charophytes de l' «Aquitanien» de Suisse occidental. Essai de taxonomie et biostratigraphie. Geobios, 16, 5-37.

Berger, J.-P. (1983b). Biostratigraphie de la transgression de la Molasse marine supérieure (OMM) en Suisse occidentale. Eclogae Geologicae Helvetia, 76, 729-732

Berger, J.-P. (1986). Biozonation préliminaire des charophytes oligocènes de Suisse occidentale. Eclogae Geologicae Helvetiae, 79, 897-912.

Berger, J.-P. (1987). L'évolution des végétaux: de la cellule aux angiospermes. Bulletin de la Société fribourgoise des Sciences naturelles, 76, 13-41.
Berger, J.-P. (1992a). Correlative chart of the European Oligocene and Miocene: applications to the Swiss Molasse Basin. Eclogae Geologicae Helvetiae, 85, 573-609.

Berger, J.-P. (1992b). Biostratigraphical correlations between European charophytes and mammals from the Paleocene to Middle Miocene. In J. Kovar-Eder (Ed.), Palaeovegetational development in Europe. (pp 107-110). Proceedings of the Pan-European Palaebotanical Conference, Vienna.

Berger, J.-P. (1992c). Paléontologie de la Molasse Suisse occidentale: Taxinomie, biostratigraphie, paleoecologie, paleogéographie, paleoclimatologie. Unpublished habilitation thesis, University of Fribourg, 452 pp.

Berger, J.-P. (1996). Cartes paléogéographiques-palinspasthiques du bassin molassique suisse (Oligocène inférieur-Miocène moyen). Neues Jahrbuch für Geologie und Paläontologie Abhandlungen, 202, $1-44$

Berger, J.-P. (1999). Redefinition of European Oligo-Miocene charophyte biozonation. Australian Journal of Botany, 47, 283-296.

Berger, J.-P., \& Dupraz, C. (1995). Du singe à l'homme: une évolution de 10 millions d'années. Bulletin de la Société fribourgoise des Sciences naturelle, 84, 70-104.

Berger, J.-P., Reichenbacher, B., Becker, D., Grimm, M., Grimm, K., Picot, L., et al. (2005a). Paleogeography of the Upper Rhine Graben (URG) and the Swiss Molasse Basin (SMB) from Eocene to Pliocene. International Journal of Earth Sciences, 94, 697-710.

Berger, J.-P., Reichenbacher, B., Becker, D., Grimm, M., Grimm, K., Picot, L., et al. (2005b). Eocene-Pliocene time scale and stratigraphy of the Upper Rhine Graben (URG) and the Swiss Molasse Basin (SMB). International Journal of Earth Sciences, 94, 711-731.

Emery, E., Tütken, T., Becker, D., Bucher, S., \& Berger, J.-P. (2007). Rickenbach unter den Tropen... vor 25 Millionen Jahren! Bestimmung des Paläoklimas und der Paläoökologie anhand der Untersuchungen an fossilen Nashhornzähnen aus der Sammlung des Naturmuseums Olten. Mitteilungen der Naturforschenden Gesellschaft des Kantons Solothurn, 40, 51-64.

Emmenegger, C., Berger, J.-P., Rauber, G. et al. (2003). L'aventure de l'Univers, de la Terre et de la Vie. Georama du Gibloux, Livret-Guide, Department of Geosciences, University of Fribourg, $143 \mathrm{pp}$.

Hug, W.A., Becker, D., Marty, D., \& Oriet, A. (2004). La Section de paléontologie de la République et Canton du Jura: une brève présentation. Actes 2003 de la Société Jurassienne d'Émulation, 2003, 9-26.

Kälin, D., Berger, J.-P., Engesser, B., \& Weidmann, M. (2001). Paléontologie et âge de la Molasse d'eau douce supérieure neuchâtelois. Schweizerische paläontologische Abhandlungen (Mémoires suisses de Paléontologie), 121, 63-99.

Marty, D. (2008). Sedimentology, taphonomy, and ichnology of Late Jurassic dinosaur tracks from the Jura carbonate platform (Chevenez-Combe Ronde tracksite, NW Switzerland): insights into the tidal-flat palaeoenvironment and dinosaur diversity, locomotion, and palaeoecology. GeoFocus, 21, $278 \mathrm{pp}$.

Marty, D., Ayer, J., Becker, D., Berger, J.-P., Billon-Bruyat, J.-P., Braillard, L., et al. (2007). Late Jurassic dinosaur tracksites of the Transjurane highway (Canton Jura, NW Switzerland): overview and measures for their protection and valorisation. Bulletin für angewandte Geologie (Bulletin of applied Geology), $12,75-89$.

Marty, D., Belvedere, M., Meyer, C. A., Mietto, P., Paratte, G., Lovis, C., et al. (2010). Comparative analysis of Late Jurassic sauropod trackways from the Jura Mountains (NW Switzerland) and the central High Atlas Mountains (Morocco): implications for sauropod ichnotaxonomy. Historical Biology, 22, 109-133. 
Marty, D., Cavin, L., Hug, W. A., Meyer, C. A., Lockley, M. G., \& Iberg, A. (2003). Preliminary report on the Courtedoux Dinosaur Tracksite from the Kimmeridgian of Switzerland. Ichnos, 10, 209-219.

Mennecart, B., Becker, D., \& Berger, J.-P. (2010). Iberomeryx minor (Mammalia, Artiodactyla) from the Early Oligocene of Soulce (Canton Jura, NW Switzerland): systematics and palaeodiet. Swiss Journal of Geosciences, 104(Supplement 1), 115-132.

Mennecart, B., Scherler, L., Becker, D., \& Berger, J.-P. (2009). Late Oligocene changes in mammal communities of Western Europe: warming and cooling event? Journal of Vertebrate Paleontology, $29,147$.

Mennecart, B., Scherler, L., Hiard, F., Becker, D., \& Berger, J.-P. (2012). Large mammals from Rickenbach (Switzerland, reference locality MP29, Late Oligocene): biostratigraphic and palaeoenvironmental implications. Swiss Journal of Palaeontology, 131, 161-181.

Picot, L., Becker, D., \& Berger, J.-P. (1999). Nouvelles données paléoécologiques et biostratigraphiques sur la Formation des Calcaires delémontiens («Delsberger Kalke»), Oligocène terminal, Jura suisse). Neues Jahrbuch für Geologie und Paläontologie Abhandlungen, 214, 433-462.

Picot, L., Becker, D., Cavin, L., Pirkenseer, C., Lapaire, F., Rauber, G., et al. (2008). Sédimentologie et paléontologie des paléoenvironnements côtiers rupéliens de la Molasse marine rhénane dans le Jura suisse. Swiss Journal of Geosciences, 101, 483-513.
Picot, L., Becker, D., Lapaire, F., Ustaszwski, K., Hug, W. A., \& Berger, J.-P. (2005). Sédimentologie, paléontologie et paléoenvironnements côtiers de la région de Porrentruy (Sud-Rhénan, Paléogène, Jura, Suisse): implications géodynamiques. Swiss Journal of Geosciences, 98, 281-296.

Pirkenseer, C., Spezzaferri, S., \& Berger, J.-P. (2010). Palaeoecology and biostratigraphy of the Paleogene Foraminifera from the southern Upper Rhine Graben and the influence of reworked planktonic Foraminifera. Palaeontographica, A293, 1-93.

Pirkenseer, C., Spezzaferri, S., \& Berger, J.-P. (2011). Reworked microfossils as a paleogeographic tool. Geology, 39, 843-846.

Riveline, J., Berger, J.-P., Feist, M., Martin-Closas, M., Schudack, M., \& Soulie-Märsche, I. (1996). European Mesozoic-Cenozoic charophyte biozonation. Bulletin de la Société géologique de France, 167, 453-468.

Scherler, L., Becker, D., \& Berger, J.-P. (2011). Tapiridae (Perissodactyla, mammalia) of the Swiss Molasse Basin during the Oligocene-Miocene transition. Journal of Vertebrate Paleontology, 31, 479-496.

Scherler, L., Tütken, T., Vennemann, T., Becker, D., \& Berger, J.-P. (2010). Palaeoecological considerations in Oligocene vertebrates of Western Europe- $\mathrm{C}$ and $\mathrm{O}$ stable isotope compositions. Geochimica et Cosmochimica Acta, 74, A921. 